\title{
Toponímia e Línguas Indígenas do Brasil
}

\section{MARIA VICENTINA DICK}

\begin{abstract}
A acurada visão do professor Plínio Ayrosa foi a causa principal A da introdução dos estudos toponímicos na Universidade de São 1 Paulo, na recém-instalada Faculdade de Filosofia, Ciências e Letras.
\end{abstract}

Em sua origem, a Toponímia não constitui um corpo disciplinar autônomo, à semelhança do que ocorre hoje, vinculando-se à antiga cadeira de Etnografia e Língua Tupi, no âmbito dos cursos de História e Geografia. Mas o ponto vital e ordenador de todo o questionamento que se colocava era a preocupação latente com a dialetologia indígena brasileira, especialmente a tupi. A Toponímia nascente conformava, porém, um duplo objetivo: não só o ensino de suas básicas e de seus fundamentos gerais, segundo os modelos assentados pelo ramo europeu da onomástica, mas, principalmente, a funçáo instrumental de um marcador vocabular brasílico (estudo etimológico dos topônimos tupis), cuja freqüência, no sistema lexical português, sempre atingiu índices expressivos nos mais variados itens semânticos (a exemplo de zoonímia, fitonímia, hidronímia geomorfonímia, ergonímia).

Era natural, assim, que as primeiras pesquisas toponímicas resultantes tivessem um enfoque de natureza ameríndia, como se depreende dos trabalhos então publicados (cf. Drumond, 1954, 1965; Magalhães, 1985).

A reformulação dos cursos de Letras, no final da década de 60 , trouxe, como conseqüência, o desdobramento do antigo conteúdo programático em duas disciplinas autônomas, hoje integrantes da área de Línguas Indígenas do Brasil, e alocadas no Departamento de Letras Clássicas e Vernáculas, ou seja, Língua Tupi e Toponímia (curricularmente, compóem o núcleo da área Cultura Brasileira do CMF). Com isso, alargou-se o campo de trabalho natural, principalmente a partir de quando se fixou melhor a sua nomenclatura na estrutura curricular de Letras (1987).

Não há dúvida de que a atual disciplina Toponímia Geral e do Brasil compreende, agora, um espaço muito mais amplo, direcionan- 
do-se, objetivamente, não apenas ao campo teórico-metodológico e analítico-comparativo (parte genérica e universalizante) (cf. Dick, 1980), como ao campo aplicado ou prático-experimental (cf. Dick, 1988). Nessa linha de pesquisa, desenvolvida sistematicamente, situamse vários projetos, alguns em sua fase final, como os que se mencionam:

- vocabulário geográfico de origem indígena brasileira (famílias TupiGuarani, Karib, Aruak e algumas do tronco Macro-Jê, presentes na Toponímia);

- estudo histórico-toponímico das ruas da cidade de Sáo Paulo (concluídos: Centro Velho e Centro Novo; bairros periféricos: em andamento);

- catalogação do acervo bibliográfico toponímico na Universidade de Sáo Paulo (em execução);

- Atlas Toponimico do Estado de São Paulo - Projeto ATESP (variante regional do Atlas Toponimico do Brasil) - Financiamento: $\mathrm{CNPq}$, Fapesp e USP (Análise do comportamento da nomenclatura geográfica dos municípios paulistas: aspectos etno-lingüísticos, semânticos, morfológicos e históricos dos topônimos estaduais).

Três fatos relevantes devem ser destacados, nesta oportunidade:

- a continuidade de iniciativa pioneira do professor Ayrosa ao propor a introdução dos estudos toponímicos na Universidade de Sáo Paulo, consolidados, depois, pela perseverança do professor Carlos Drumond;

- a abertura de novas linhas de estudo dentro da temática geral dos nomes, como a Toponímia urbana, de feição nitidamente interdisciplinar, e a Antroponímia, em suas modalidades técnicas, etno-sociais grupais e motivadoras;

- a criação (1984) também pioneira e a efetivação (1989) de um curso de pós-graduação em estudos onomásticos (Toponímia e Antroponímia) visando à formaçáo de um corpo próprio de pesquisadores, à semelhança do que ocorre em outras instituiçốs européias e americanas.

Maria Vicentina de Paula do Amaral Dick é professora do Departamento de de Letras Clássicas e Vernáculas da Faculdade de Filosofia, Letras e Ciências Humanas da USP. 